\title{
Pendidikan Multikultural Sekolah Dasar di Wilayah 3T
}

\author{
Daniel Dike \\ dikedanieltukan@gmail.com/dickytoekan@yahoo.co.id
}

\begin{abstract}
Abstrak
Masyarakat di wilayah perbatasan tidak hanya diperhadapkan dengan isu eksploitasi ekonomi dan sumber alam namun juga terjadinya kesenjangan sosial karena tidak meratanya pembangunan. Adanya kecenderungan bahwa ketika kelompok lain tidak kompatibel, beda ideologi atau pilihan politik maka respon sosial cenderung negatif, berprasangka jahat (prejudice) bahkan tindakan anarkis. Penelitian ini adalah penelitian deskriptif fenomenologis dengan mengkaji fenomena faktual masyarakat multikultural Kabupaten Sintang di wilayah Sektor Timur Kalimantan Barat. Data dianalisis mengunakan kajian pustaka. Output riset ini adalah memberi kontribusi pemikiran untuk menggali keberagaman dan keunggulan sekolah dasar di daerah pedalaman.
\end{abstract}

Kata kunci: pendidikan multikultural, keragaman, sekolah dasar, wilayah pedalaman. 


\section{PENDAHULUAN}

Fakta sosial emperis saat ini memperlihatkan bahwa bangsa Indonesia khususnya wilayah-wilayah perbatasan seperti di sektor Timur Kalimantan Barat diperhadapkan dengan tuntutan dan tantangan regional dan global. Masyarakat tidak hanya diperhadapkan dengan isu eksploitasi ekonomi dan sumber alam namun terjadinya kesenjangan sosial karena tidak meratanya pembangunan. Paradigma pembangunan dari pinggiran Presiden Jokowi mulai menampakan hasil namun belum signifikant mencegah ketertinggalan. Isu SARA dalam agenda pilkada membenamkan nalar akal sehat. Spanduk intoleran terpasang di tengah dan sudutsudut ibukota, stigma pengkafiran, isu bangkitnya komunis, antek asing-aseng menggelinding liar dan jadi perang media sosial.

Adanya kecenderungan masyarakat saat ini bahwa ketika kelompok lain tidak kompatibel, beda ideologi atau pilihan politik maka respon sosial juga cenderung negatif, berprasangka jahat (prejudice) bahkan melahirkan perilaku dan tindakan anarkis. Meme lucu tak ber-etika ramai di media sosial bahkan seorang presiden dan mantan presiden pun dicaci maki atau dibully. Anak usia sekolah dasar diikutkan dalam demonstrasi dengan membawa tulisan di punggung, "kami kebal peluru." Herdi Sahrasad, (Kompas, 6 April 2017) mencatat bahwa kasus Tolikara, Tanjung Balai, dan Pilkada DKI yang menimpa Basuki Tjahaja Purnama selalu terkait isu SARA. Meski sejak awal kemerdekaan kita sudah berkomitmen dan menyuarakan Pancasila, masalah kebinekaan atau multikulturalisme ternyata belum selesai. Perseteruan semacam ini akan terus berjalan seiring waktu dan perkembangan politik dan demokrasi yang tak kunjung dewasa. Tentang realitas pluralisme Indonesia, SriEdy Swasono (2012:4) menjelaskan bahwa Indonesia diperkirakan terdiri dari 520 budaya yang tersebar di 17.000 pulau. Keragaman ini sangat potensial bagi pembangunan dan kemajuan bangsa tetapi serentak juga sebagai potensi konflik jika masyarakatnya tidak cerdas.

Keragaman Indonesia menjadi lebih krusial ketika berhadapan dengan globalisasi dan perkembangan ipteks. Globalisasi tidak hanya mengenai budaya lokal tetapi juga tentang masuknya budaya global. Sebut saja kasus dugaan penistaan agama Gubernur DKI (Ahok) meluas dan jadi viral karena peran media sosial. Globalisasi tidak hanya mengenai sebuah budaya dunia tetapi justru melahirkan 
sebuah budaya baru yaitu budaya maya (cyber culture). Budaya ini dibangun oleh komputer, handphone, gaget dengan vitur, perangkat-perangkat jejaringnya. Budaya ini dihubungkan oleh ruang-ruang cyber, wilayah tanpa batas, dimana lalulintas informasi dan ilmu pengetahuan, dengan kecepatan cahaya elektronik menyediakan, memproduksi dan merekaiasa, tulisan, gambar, vidio, musik, entertaint, games dalam berbagai ukuran dan indikatornya. Tilaar, (2004:73) menyatakan bahwa cyber culture melahirkan sebuah budaya maya berupa geogerafi mental, dibentuk oleh adanya konsensus dan revolusi teritori mental yang dipenuhi data dan kebohongan, jutaan suara dengan mata bisu, tak tampak, dimana keseluruhannya menimbulkan rasa ingin tahu, ingin berbagi mimpi dan sebagainya."

Disadari atau tidak siswa sekolah dasar saat ini telah memasuki zona budaya maya bahkan menjadi aktor sekaligus korban dalam wilayah geogerafi mental tersebut. Tidak lagi baru dan mengherankan bahwa anak-anak sekolah dasar di kota Sintang mempunyai akun pribadi seperti facebook, instagram,telegram sehingga kapan saja dapat meng-update status, merekaiasa gambar, berita dan mem-posting ke wilayah publik. Siswa sekolah dasar sudah mampu mengeskprsikan dirinya dengan bebas dengan siapa pun, merasa ok, hebat, terkenal, dan berlomba mengumpulkan teman sebanyak-banyaknya di media sosial. Wilayah sosial siswa tidak lagi dibatasi tembok rumah dan halaman sekolah tetapi diukur oleh kemampuan dan waktu mereka berkutat menjangkau siapapun dan apapun dengan teknologi informasi.

Kontradiksi justru terjadi untuk siswa di area pedalaman dan perbatasan. Kebanyakan siswa tidak kenal dan paham dengan teknologi informasi, internet atau media sosial. Dunia sosial dan belajar anak pedalaman lebih natural dan alamiah tanpa memikirkan signal dan pulsa. Kecerian mereka adalah menangkap ikan, mencari buah buahan hutan, mandi di sungai dan berkebun. Dunia sekolahnya dilingkupi oleh wilayah dengan infrastuktur, tenaga guru maupun fasilitas sekolah yang minim. Di akhir tahun anak-anak ditagih hasil belajarnya dengan standar nasional. Sebuah ketimpangan sosial yang disadari tetapi sulit diatasi. Ketidakadilan nyata dunia pendidikan namun tak pernah di bawa ke meja hijau.

Beberapa kesimpulan observatif yang dilakukan pada beberapa sekolah negeri dan swasta di kota Sintang bulan Agustus-Desember 2016 ditemukan fenomena faktual sebagai berikut: 
1. Umumnya sekolah SD perkotaan telah memiliki jaringan internet namun belum banyak guru dan siswa memanfaatkan fasilitas tersebut meskipun sering terkendala listrik dan kemacetan pada sistem jaringan dan signal.

2. Kurikulum muatan lokal lebih banyak diterjemahkan sebagai pengajaran dan pembelajaran bahasa asing, Mandarin, Inggris, Arab dan kegiatan ekstrakurikuler.

3. Taman dan lingkungan sekolah, konsep green school belum menjadi kesadaran seluruh warga sekolah.

4. Penataan ruang-ruang kelas dan lingkungan sekolah belum mengekspresikan inovasi pembelajaran guru dengan mengedepankan potensi, keunikan dan keunggulan budaya-budaya lokal meskipun bantuan operasional sekolah sudah cukup besar.

5. Penyusunan program-program sekolah dan pendataan (data base sekolah) belum rapih, belum banyak melibatkan peran semua guru dan komite secara optimal dan terorganisir.

6. Minimnya program sekolah dan dinas pendidikan yang memberi kesempatan yang merata dan adil kepada semua guru untuk mendapatkan pelatihan-pelatihan (program upgrading) untuk meningkatkan kualitas dan daya saing guru.

7. Kerja sama dengan perguruan tinggi dan lembaga internasional seperti BRIGEAustralia Indonesia School Patnership masih terbatas dan sifatnya korespondensial. Program semacam ini belum diperluas dalam program-program konkrit sekolah untuk perbaikan mutu guru, management dan kepemimpinan kepala sekolah.

Fenomena-fenomena tersebut merupakan penguatan data atas masalah klasik pendidikan Indonesia. Deputi SDM Bappenas, Laila Ratna Komala (Kompas, 27 Maret 2001) menjelaskan bahwa ada tiga persoalan besar pendidikan Indonesia yang sulit diurai yaitu: (1) masih rendahnya pemerataan memperoleh pendidikan (2) masih rendahnya kualitas dan relevansi pendidikan, dan (3) masih lemahnya manajemen pendidikan. Ketiga persoalan ini belum terselesaikan sampai saat ini maka sangat penting bahwa upaya perbaikan harus terus dikerjakan. 


\section{METODE}

Penelitian ini adalah penelitian deskriptif fenomenologis dengan mengkaji fenomena faktual masyarakat multikultural di Kabupaten Sintang di wilayah Sektor Timur Kalimantan Barat dan harapannya bagi inovasi pendidikan dasar di masa depan. Data dianalisis mengunakan pendekatan teoretis ilmiah (bedah pustaka) dengan mengkombine beberapa teori pendidikan multikultural dan teori-teori pendidikan lain yang relevan. Output riset ini adalah memberi kontribusi pemikiran atau perspektif lain untuk menggali keberagaman dan keunggulan lokal sekolah di daerah dari kaca mata pendidikan multikultural sekolah dasar.

\section{HASIL PENELITIAN DAN PEMBAHASAN}

\section{Perspektif Pendidikan Multikultural}

Secara etimologis istilah multikultural dibentuk dari dua kata yakni multi dan kultural. Multi berarti banyak, ragam, aneka, bermacam-macam. Sedangkan kultural berarti budaya. Jadi multikultural secara sederhana dapat diartikan sebagai keragaman budaya. Pendidikan multikultural secara etimologis juga dibentuk dari dua kata yakni pendidikan dan multikultural. Zamroni, (2003:24) mendefinisikan pendidikan dalam arti luas sebagai proses yang berkaitan dengan upaya mengembangkan diri seseorang pada tiga aspek. Konsep ini sejalan dengan gagasan Dewey, (1944:1-4) bahwa pendidikan adalah process of facilitating learning or the acquisation of knowledge, skills, values, beliefs and habits. Dengan demikian pendidikan multikultural secara sederhana diartikan sebagai upaya memfasilitasi keragaman budaya peserta didik dalam berbagai aspeknya di sekolah.

Secara historis, pendidikan multikultural berkembang di Eropa, Amerika, Kanada dan negara-negara maju lainnya pada dekade 1970 sampai 1980-an, terutama di lembaga-lembaga pendidikan. Konsep ini lahir karena lembaga pendidikan dan kebijakan pemerintah memanfaatkan keanekaragaman masyarakat sebagai potensi membangun negara. Karīm al-Hussaini dan Aga Khan Muslim Ismaili (Zamroni, 2014: 14) tokoh muslim dan anggota parlement Kanada mengungkapkan peran penting keberagaman bahwa:

"the most successful pluralist society on the face of our globe, citing it as a model for the world. The experience of Canadian governance its commitment to pluralism and its support for the rich multicultural diversity 
of its peoples is something that must be shared and would be of benefit to all societies in other parts of the world."

Pengalaman spiritual masyarakat Kanada menjelaskan esensi dan eksistensi pendidikan multikultural sebagai nilai (vallue), bagaimana masing-masing kelompok atau lembaga seperti sekolah bersedia untuk menyatu (integrate) tanpa mengabaikan keragaman budaya yang dimiliki. Sekolah sebagai miniatur masyarakat maupun individu melebur dalam proses hibridisasi dimana setiap individu tidak menonjolkan perbedaan atau dominasi budaya tertentu.

Parsudi Suparlan, (2004) menegaskan bahwa multikulturalisme lebih merupakan sebuah idelogi, atau paham yang memberikan ruang nyaman bagi paradigma perbedaan, dan menjadi salah satu entitas mendasarkan kemanusiaan seorang manusia. Setiap warga negara Indonesia apapun budaya, agama, etnis, pandangan politik mengakui pluralisme sebagai corak hidup (the way of life). Implikasinya adalah pendidikan dipandang sebagai rangkaian keyakinan (set of belief). Artinya, pendidikan memfasilitasi keragaman budaya, etnis, gaya hidup, perbedaan latar sosial setiap individu maupun kelompok untuk memperoleh akses yang sama dan adil.

Pendidikan multikultural sebagai way of life berfungsi untuk membentuk perilaku manusia menuju sebuah pluralisme konstruktif yang telah disepakati oleh UNESCO tahun 1999 di Paris (Eddy Kristiyanto dan William Chang, 2014:xi). Pendidikan multikultural menjadi relevan untuk menggali kekayaan budaya kabupaten Sintang yang kaya. Kekayaaan Sintang tidak hanya dari sisi alam, hutan yang luas, sungai besar dan indah tetapi juga sejarah Sintang yang unik dengan ragam dinamika etnisitas, seni, sastra, tenun ikat, seni lukis, tarian dalam kesatuan kultural dan religius yang khas. Rekomendasi UNESCO jelas menginginkan sebuah pluralisme konstruktif untuk membangun masyarakat dengan nilai-nilai keadaban historik yang agung.

\section{Guru dan Sensivitas Multikultural}

Belum banyak gagasan pendidikan multikultural masuk dalam konsep pendidikan sekolah dasar Indonesia. Namun demikian, penting bahwa gagasan ini memberi konsep baru kepada kepala sekolah, guru, orangtua, dan komite sekolah yayasan, dan pemerintah daerah. Menurut Banks, (2007:82), "multicultural 
education is also an educational reform movement that tries to reform schools in ways that will give all students an equel opportunity to learn. It describes teaching strategis that empower all students and give them voice." Pendidikan multilkultural sebagai gerakan perubahan reformasi sekolah dimana semua siswa mendapatan kesempatan yang sama untuk belajar dan mendapatkan hak-haknya secara adil.

Salgur dan Gursoi (2015: 15) dalam risetnya tentang "Multicultural Education and Teacher's Characteristic" menyimpulkan bahwa sensivitas multicultural sangat penting sebagai penentu keberhasilan siswa dalam proses belajar di kelas. Ia berkeyakinan bahwa:

"Nowadays, the societies that have a homogeneous structure are increasingly rare. The more and more numerous multicultural environments bring about positive and negative results. Moreover, every culture's multicultural structure is changing day by day. For example, due to various reasons, nowadays, living in a foreign country as a stranger and living together with foreigners is something that occurs quite frequently."

Sekolah dasar bisa menjadi instrumen terjadinya perubahan sosial melalui reformasi kurikulum. Reformasi kurikulum dapat tercermin dalam pengembangan model pembelajaran multikultural sekolah dasar. Riset dari Farida Hanum dan Setya Rahardja (2006) tentang pengembangan model pembelajaran pendidikan multikultural menunjukan bahwa modul pendidikan multikultural efektif diterapkan di kelas empat sekolah dasar Yogyakarta. Modul pendidikan multikultural yang mengambil subyek eksperimen guru, siswa, orangtua dan komite sekolah dapat dijadikan sebagai pedoman dalam pengembangan pendidikan multikultural sekolah dasar. Ketika guru memiliki pemahaman dan sensivitas multikultural yang baik maka kepekaan tersebut termanifestasi dalam inovasi pembelajaran melalui eksperimen menerapkan modul pendidikan multikultural yang telah terbukti efektif.

\section{Mengembangkan Lingkungan Multikultural Sekolah Dasar}

Kultur sekolah yang baik menurut Zamroni, (2011:111) harus bersifat terbuka, demokratis dan menghormati kerja keras, kejujuran, solidaritas dan kesetiakawanan sosial. Tujuannya adalah memperkuat persaudaraan, memberi ruang kebebasan bagi setiap siswa untuk mengekspresikan diri. Keberhasilan pendidikan multikultural tidak hanya terjadi pada aspek kurikulum saja tetapi pada lingkungan dan actor pendidikan. Pendidikan multikultural menjadi tidak efektif pada lingkungan sekolah 
yang tidak ramah dan guru dengan sikap negatif terhadap siswa. Guru perlu memahami bahwa individu siswa memiliki kelompok yang beragam dan ditentukan oleh banyak aspek seperti gender, kelas sosial, etnis, ras, agama, kondisi fisik, kecacatan dan kebangsaannya. Semua aspek tersebut dalam konsep Banks (2005:14 \& Gorsky, 2008) berpengaruh kuat terhadap individu siswa. Pendidikan multikultural di sekolah harus memperkuat hubungan interaksi verbal (dialog) antara guru dan siswa terutama terhadap siswa dari tingkat ekonomi, etnis dan agama minoritas. Norma-norma kelembagaan direkonstruksi agar memenuhi rasa keadilan. Adanya pemerataan kesempatan bagi guru dan siswa untuk berkembang. Lingkungan sekolah sebagai sistem sosial harus demokratis dan menggerakan semua komponen agar berjalan baik dan produktif. Hubungan dan peran keberagaman individu siswa tergambar dalam konsep Banks pada gambar 1 berikut:

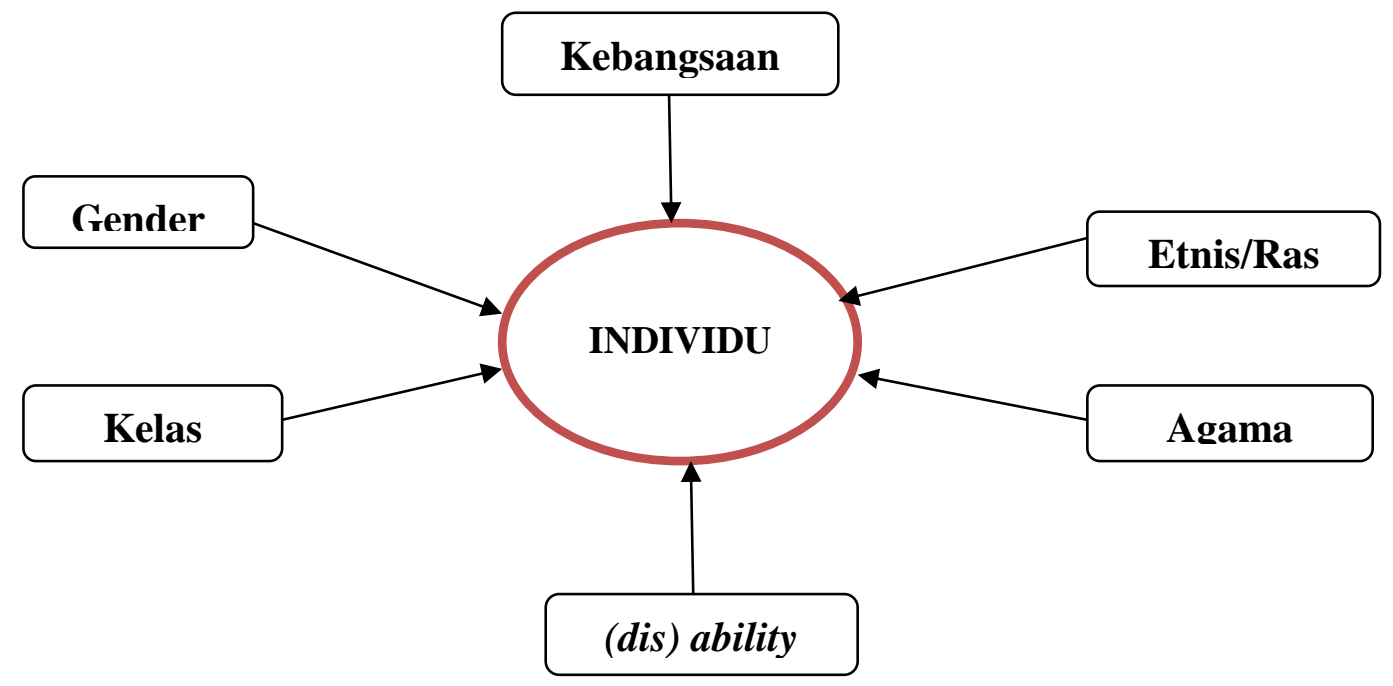

Gambar 1

Keanggotaan kelompok beragam pada individu (Banks, 2005:14).

\section{Pentingnya Pedagogi Kritis Sekolah Dasar}

Di sekolah-sekolah dasar kebanyakan, siswa lebih banyak diajari tentang bagaimana berpikir dari pada mengenai apa yang dipikirkan. Siswa semestinya dilatih dan dibiasakan memahami semua jenis pengetahuan, aktif mengkonstruksi pengetahuannya (knowledge construction) dan membiasakan interprestasi yang berbeda-beda dari setiap siswa. Siswa perlu ditanamkan pengetahuan dan kesadaran akan adanya perbedaan dalam masyarakat Indonesia. Siswa harus belajar bahwa semua pengetahuan yang mereka peroleh terdapat interprestasi yang beraneka ragam. 
Interprestasi juga ditentukan oleh kepentingan masing-masing orang atau lembaga dan terkadang interprestasi-interprestasinya bertentangan dengan sudut pandang siswa sendiri.

Pendidikan Indonesia belum banyak berpihak kepada sekolah-sekolah di daerah apalagi pedalaman dan perbatasan seperti Kalimantan Barat dan wilayah Indonesia bagian Timur. Hommond, French \& Lopes dkk, (2002:9), bahwa sekolah sebagai miniatur masyarakat terdapat banyak gap antara haves and the have's not. Berita online yang dimuat (http://www.bbc.com/indonesia/trensosial) menceritakan siswa pedalaman Kalimantan Barat meminta presiden mengirimkan baju seragam. Fakta ini secara telanjang mata mengambarkan kondisi riil pendidikan di daerah. "Dengan mengenakan seragam lusuh, dengan sandal, dan sebagian tanpa alas kaki, serta tas kresek, anak-anak sekolah dasar di Desa Sungkung, Bengkayang, mengatakan "Pak Jokowi minta tas." Video pendek yang diunggah langsung oleh sang guru bernama Anggit Purwoto yang telah bertugas di pedalaman Bengkayang tujuh bulan terakhir." (bbc.com,5/4/2017 diakses 9/4/2017). Vidio tersebut membuat presiden jatuh hati dan secara diam-diam mengirim bantuan seragam dan perlengkapan sekolah kepada siswa di sekolah dasar SDN 04 Sungkung Bengkayang (https://news.detik.com).

Kesenjangan sungguh nyata. Apa jadinya ketika guru yang bernama Anggit Purwoto tak mengirim vidio tersebut ke media sosial? Bagaimana nasib anak-anak bangsa di pedalaman Kalbar jika sosok guru seperti Anggit Purwoto absen di wilayah-wilayah pedalaman seperti itu? Apakah "budaya diam" dan sikap tak peduli atau "acuh tak acuh" pemerintah sudah menjadi hal yang biasa? Kasus di SDN 04 Sungkung Bengkayan dan banyak contoh kisah miris lainnya di berbagai wilayah Sektor Timur Kalbar menjadi contoh nyata bagaimana realita haves and the haves not dunia pendidikan Indonesia masif di daerah 3T. Pendidikan Indonesia seolaholah hanya untuk anak perkotaan dan kalangan menengah atas yang mendapatkan akses layak. Sementara, anak-anak pedalaman dengan kondisi apa adanya mendapatkan pendidikan yang juga apa adanya. Freire, (1982:25) mengecam keras bahwa situasi seperti ini sungguh tidak manusiawi dan tidak demokratis.

Menuju pendidikan multikultural sekolah dasar, Marri (2005:107) menjelaskan bahwa sekolah harus dikembangkan dengan kerangka Cllasroom Based Multicultural Democratic Education (CMDE) dengan tiga unsur utama yaitu (1) 
building of community (2) thorought dicipnary content (3) critical pedagogy. Konsep membangun komunitas adalah mengupayakan kelas yang kolaboratif dan saling menghargai perbedaan. Siswa belajar saling menghargai satu sama lain melalui diskusi, kerja kelompok, pemecahan masalah sehingga dibangun pemahaman, nilai dan sikap hidup demokratis. Mengenai konten mata pelajaran yang cermat, muatannya meliputi pengetahuan akdemis pokok dan pengetahuan akademis transformatif, emansipatoris (Zamroni, 2002:77 dan Palmer, 2010:215). Pada aspek konten siswa wajib dibekali pengetahun dan keterampilan sehingga siswa dapat berpartisipasi dan berkontribusi dalam masyarakat. Sedangkan pendidikan kritis tekananya pada penggunaan pengetahuan akademik transformatif agar membuat siswa sadar akan kondisi sosial politik dalam masyarakat sehingga ia mampu menjadi agen perubahan (agent of change) dalam masyarakat.

\section{PENUTUP DAN KESIMPULAN}

Pendidikan multikultural dapat tumbuh dan hidup di sekolah dasar pedalaman dan wilayah 3T jika warga sekolah baik kepala sekolah, guru, siswa, orangtua yayasan, dinas pendidikan membiasakan beberapa aspek-aspek penting sebagai nilai dalam proses pendidikan anak sebagai berikut: (a) Membiasakan untuk tidak berpikir dan berperilaku diskriminatif, yaitu sikap untuk tidak memperlakukan orang atau individu tertentu lebih baik dari orang lain. (b) Memahami persepsi orang lain, sekolah membutuhkan ruang dinamis untuk menguji pendapat, gagasan, masukan, dengan mengajak diskusi dan dialog serta menghindari penyempitan wawasan dan dominasi tunggal pada kekuatan seorang atau kelompok tertentu. (c) Menghindari sterotipe dengan membangun kultur respect for others yakni perasaan simpati dan empati sesuai kultur masyarakat tiap-tiap daerah. (d) Mengembangkan kesetaraan dan keadilan sosial, yakni memberikan kesempatan dan akses yang sama kepada semua budaya, etnis dan agama di sekolah. Setiap guru maupun siswa diberi hak untuk memperoleh fasilitas, kesempatan berkembang serta layanan belajar yang sama dan adil terutama siswa dengan kondisi kecacatan tertentu (dis-ability). Harapannya, ketika nilai dan sikap multikultural telah menjadi the way of life masyarakat dan warga sekolah maka perlahan dan bertahap perbaikan pendidikan maupun kesenjangan pendidikan di wilayah terluar, terdepan dan tertinggal tahap demi tahap diatasi. 


\section{DAFTAR PUSTAKA}

Banks, James A, (2005). Multicultural Education: Issues and Perspectives the 5th. New York, John Wiley \& Son Inc.

Eddy Kristiyanto, A dan William Chang, (2014) Multikulturalisme: Kekayaan dan tantangannya di Indonesia. Jakarta: Penerbit Obor.

Farida Hanum dan Setya Rahardja, (2010). Implementasi Model Pembelajaran Multikultural di Sekolah Dasar Provinsi Daerah Istimewa Yogyakarta. Jurnal Penelitian Ilmu Pendidikan. Volume 3 Nomer 1, Maret 2010.

Paolo Freire, (1982). Pedagogy of the Oppressed. Harmondsworth: Pinguin.

Hammond, Linda D, French, Jeniffier \& Gracia Lopes, Silvia Paloma, (2002). Learning to teach for social justice. New York: Teachers Colege Press, Colambia University.

Herdi Sahrasad (2017) Indonesia dan Akomodasi Multikultural (Opini, Kompas) http://print.kompas.com/baca/opini/artikel/2017/04/06/. Diakses 07/4/ 2017.

Marri, A.R. (2005). Building a framework for clasroom based multicultural democratic educations: learning from three skilled teachers. New York: Teachers Collage Record.

Palmer, Joy A. (2010). 50 Pemikir Paling berpengaruh terhadap dunia pendidikan moderen. Yogyakarta. Penerbit Laksana.

Salgur, S.A \& Gursoi, A. (2015). Multicultural Education and Teacher's Characteristics. Euromentor Journal, 6 (3), 7-18.

Tilaar, H.A.R. (2004). Multikulturalisme: Tantangan-tangan global masa depan dalam transformasi pendidikan nasional. Jakarta. Grasindo.

Zamroni, (2003). Pendidikan untuk demokrasi. Yogyakarta. BIGRAF Publishing.

(2011). Pendidikan demokrasi pada masyarakat multikultural. Yogyakarta. Surya Sarana Grafika.

(2011). Research in multicultural education: a reader. Graduate Program UNY. (diktat untuk Mata Kuliah Pendidikan Multikultural Pasca Sarjana UNY 2015). 